\title{
Microbial fuel cell with a polypyrrole/ poly(methylene blue) composite electrode
}

\author{
This article was published in the following Dove Press journal: \\ Reports in Electrochemistry \\ 18 September 2012 \\ Number of times this article has been viewed
}

\section{Jonathan M Godwin \\ Richard W Evitts \\ Glyn F Kennell}

Department of Chemical and Biological Engineering, University of Saskatchewan, Saskatoon, Saskatchewan, Canada
Correspondence: Glyn F Kennell Department of Chemical and Biological Engineering, University of Saskatchewan, Saskatoon, Saskatchewan S7N 5A9, Canada $\mathrm{Tel}+\mathrm{I} 306966786$ I

Fax + I 3069664777

Email gfk328@mail.usask.ca

\begin{abstract}
Different configurations of anodic and cathodic half-cells were incorporated into a microbial fuel cell to determine the effectiveness of a composite electrode. This novel composite electrode consisted of poly(methylene blue) and polypyrrole electrodeposited onto a stainless steel electrode. The novel electrode/immobilized mediator was incorporated into a microbial cathodic half-cell that relied on the microalgae Chlorella vulgaris for photosynthesis, and was a net reducer of carbon dioxide. Similar microbial cathodic half-cells were also examined using electrodes fabricated from graphite and graphite deposited with methylene blue. Results from using these three different electrodes in the microbial cathodic half-cell were examined and compared with the results from others. The electrode using the novel immobilized mediator demonstrated the highest short circuit current density of $65 \mathrm{~mA} / \mathrm{m}^{2}$ when compared with other C. vulgaris systems. Different anodic half-cells were also incorporated into the microbial fuel cell and tested. Anodic half-cells tested included a microbial half-cell containing Saccharomyces cerevisiae and one containing no microbial material and based on purely chemical constituents. In the case of the microbial anodic half-cell, different electrodes, including the novel immobilized mediator/electrode, were tested. It was found that the anodic half-cell performed better with a soluble mediator than an immobilized mediator/electrode. In the case of a fuel cell where both the anodic and cathodic half-cells are microbial, our results demonstrate better performance than previous systems by using a soluble mediator in the anodic half-cell with an immobilized mediator in the cathodic half-cell.
\end{abstract}

Keywords: microbial fuel cell, biocathode, immobilized mediator, stainless steel electrode

\section{Introduction}

Microbial fuel cells are a method of generating power that take advantage of the oxidation and reduction processes which take place in microorganisms. Typically, electroactive bacteria are used in bioanodic half-cells and, when grown anaerobically, transfer some of the electrons produced from substrate oxidation to an electrode. In a microbial fuel cell, the anodic chamber is usually separated from the cathodic chamber by a proton or cation exchange membrane. Usually an oxidant, such as ferricyanide or oxygen, is used as the electron acceptor. Ferricyanide is not easily regenerated and usually requires regular replacement. Using oxygen requires expensive catalysts, typically precious metals such as platinum. Therefore, alternatives to these two options may prove beneficial.

Biocathodic half-cells provide an alternative arrangement that can reduce various substances without the need for expensive electrocatalysts. Oxidants reported to be useful in biocathodic half-cells include nitrate, ${ }^{1}$ oxygen, ${ }^{2}$ and carbon dioxide. ${ }^{3}$ 
Oxygen biocathodes include seawater biofilms ${ }^{4}$ and isolated bacteria, ${ }^{5}$ both of which catalyze oxygen reduction with an electrode acting as the electron donor. Carbon dioxide reduction in the cathodic chamber is a relatively new concept. Microalgae $^{3}$ and photosynthetic bacteria ${ }^{6}$ have been used successfully as catalysts in the cathodic chamber. The former is used with methylene blue as a mediator, while the latter is grown as a biofilm and no electron mediator is used. The power performance of these photosynthetic biocathodic half-cells is low compared with oxygen and nitrates, but they can offer other potential benefits, such as $\mathrm{CO}_{2}$ reduction, and generate useful products.

Immobilized mediators have been used with some success in various types of microbial fuel cells. Methods have included using metal ions in graphite materials, ${ }^{7}$ which significantly enhances current and power generation in bacterial anodic half-cells. Mediators that are negatively charged ions have been used as doping ions in polypyrrole films to enhance power generation in bioanodes. ${ }^{8}$ Both of these approaches make the electron transfer easier, even in microorganisms that exhibit mediatorless electron transfer. Polyaniline, another conductive polymer, has been used in microbial fuel cells in combination with carbon materials that appear to catalyze electron transfer., ${ }^{9,10}$

Attempts to use stainless steel, useful because of its durability and longevity, have been made in a few microbial fuel cell experiments. One problem that arises with stainless steel is the formation of a metal oxide layer that can inhibit electron transfer and conduction. Stainless steel electrodes have been tested in a marine fuel cell in place of traditional carbon electrodes. ${ }^{11}$ Stainless steel has been found to have lower performance than carbon, but is more easily scaled to larger systems. Further study of the performance of stainless steel outside of ocean environments is required. Manohar and Mansfeld showed that addition of stainless steel balls to a graphite anode decreased cell resistance, as measured by electrochemical impedance spectroscopy. ${ }^{12}$ This is likely a result of increased surface area, but indicates that the metal oxide layer will not completely inhibit electron transfer.

In this research, a microbial fuel cell with a photosynthetic carbon dioxide-reducing biocathodic half-cell using a unicellular microalgae and fermentative yeast anode was investigated with a newly developed immobilized mediator electrode consisting of stainless steel with layers of electrodeposited polypyrrole and poly(methylene blue). The microbial fuel cell was characterized and its performance evaluated by examining steady state voltage-current curves and open circuit measurements. Further comparisons were made between different electrode/mediator systems.

\section{Materials and methods Microbial fuel cell construction}

In this research, a two chamber microbial fuel cell was constructed from $1 \mathrm{~L}$ glass bottles. A schematic of the experimental apparatus is shown in Figure 1. The compartments were separated by a Nafion-112 proton exchange membrane with an area of $5 \mathrm{~cm}^{2}$ that was activated in $4 \mathrm{M} \mathrm{H}_{2} \mathrm{SO}_{4}$. Although different configurations of half-cells were tested, $500 \mathrm{~mL}$ of medium was used in each chamber for all configurations. Electrodes were inserted through the lids and sealed to prevent air exchange and contamination. Different electrodes were tested and were based on either type $304 \mathrm{~L}$ stainless steel or graphite rods. The rods were $0.63 \mathrm{~cm}$ in diameter and inserted $6 \mathrm{~cm}$ into the solution to give an effective electrode area of $11.3 \mathrm{~cm}^{2}$. For the cathodic half-cell utilizing the microalgae Chlorella vulgaris to reduce carbon dioxide, the following reaction for photosynthesis and consumption of $\mathrm{CO}_{2}$ occurred:

$$
6 \mathrm{CO}_{2}+12 \mathrm{H}^{+}+12 \mathrm{e}^{-} \rightarrow \mathrm{C}_{6} \mathrm{H}_{12} \mathrm{O}_{6}+3 \mathrm{O}_{2}
$$

For the anodic half-cell utilizing Saccharomyces cerevisiae, assuming complete oxidation of the sugar, the following reaction occurred:

$$
\mathrm{C}_{6} \mathrm{H}_{12} \mathrm{O}_{6}+6 \mathrm{H}_{2} \mathrm{O} \rightarrow 6 \mathrm{CO}_{2}+24 \mathrm{H}^{+}+24 \mathrm{e}^{-}
$$

Two calibrated gas flow meters were used to control the flow of carbon dioxide and air into the cathodic half-cell. The gas was bubbled into the solution with a pipette because mass transfer of $\mathrm{CO}_{2}$ was previously found not to be a limiting factor in algae growth. ${ }^{3}$ A total gas flow rate of $200 \mathrm{~mL}$ per minute was used with the biocathode. Light was provided to the cathodic chamber for 16 hours per day.

\section{Composite electrode preparation}

Composite immobilized mediator electrodes were prepared from stainless steel rods with a diameter of $0.63 \mathrm{~cm}$. The steel was cut to length, sanded, polished with $0.3 \mu \mathrm{m}$ alumina, and rinsed with acetone before deposition of polymer layers. Polypyrrole was used as a conductive layer on the stainless steel to prevent oxidation of the steel during mediator deposition and microbial fuel cell operation. Polypyrrole was selected because it is relatively stable in aqueous solution in the voltage range required for mediator polymerization and microbial fuel 


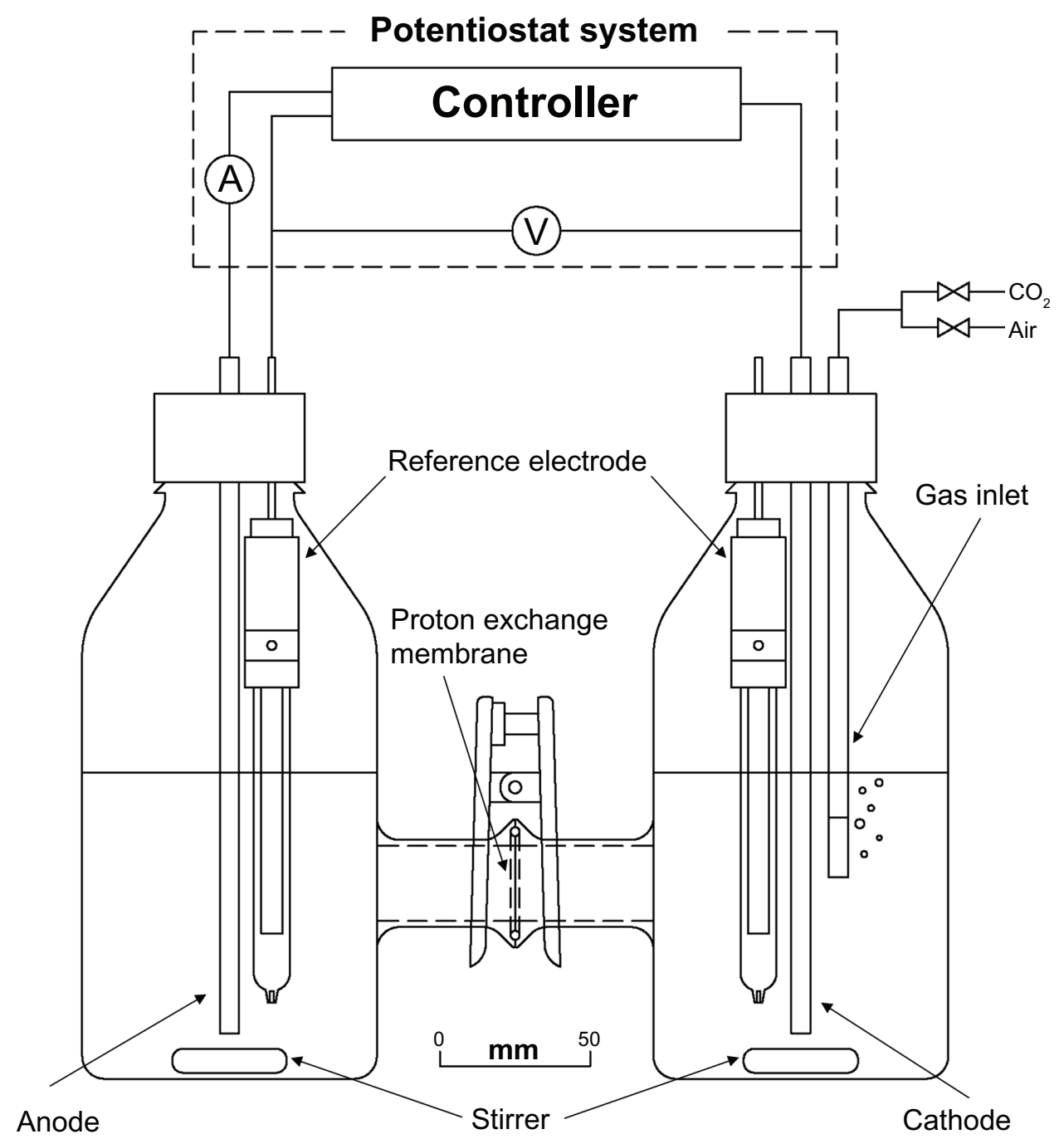

Figure I Schematic diagram of the microbial fuel cell setup with the photosynthetic biocathodic chamber on the right and anodic chamber on the left.

cell operation, and can be electropolymerized directly onto an electrode surface. Pyrrole was polymerized from aqueous solutions containing $0.25 \mathrm{~mol} / \mathrm{L}$ pyrrole, $0.1 \mathrm{~mol} / \mathrm{L}$ of the doping anion (sodium salicylate was used for these experiments), and phosphoric acid to adjust the $\mathrm{pH}$ to 4.5. A current density of $6 \mathrm{~mA} / \mathrm{cm}^{2}$ was applied for 180 seconds giving a uniform black polypyrrole layer on the steel.

After electropolymerization of pyrrole, methylene blue was deposited from a solution of methylene blue, sodium borate (as a buffer), potassium nitrate, and potassium hydroxide (to adjust $\mathrm{pH}$ ). The methylene blue was at a concentration of $1 \mathrm{mmol} / \mathrm{L}$ with a $\mathrm{pH}$ of 9.5 . Nitrate and borate concentrations of $0.1 \mathrm{~mol} / \mathrm{L}$ and $0.025 \mathrm{~mol} / \mathrm{L}$ were used, respectively, for all experiments, and the $\mathrm{pH}$ adjusted with potassium hydroxide. Eight to 12 cyclic potential sweeps were applied between -0.5 and $1.05 \mathrm{~V}_{\mathrm{SCE}}$ to the electrode in this solution to deposit an adherent layer of poly(methylene blue) on the electrode. Analysis and performance of these films has been reported previously by Godwin and Evitts. ${ }^{14}$

\section{Biological cultures}

C. vulgaris microalgae were obtained from Carolina Biological Supply (Burlington, NC). The growth medium used was Bold's Medium, which is commonly used for green microalgae species. The same medium was used for both the starter cultures and the microbial fuel cell cathodic chamber. The medium contains the following components (in $\mathrm{mg} / \mathrm{L}$ ): $75 \mathrm{NH}_{4} \mathrm{Cl}, 50 \mathrm{MgSO}_{4}, 100 \mathrm{~K}_{2} \mathrm{HPO}_{4}, 150 \mathrm{KH}_{2} \mathrm{PO}_{4}, 25 \mathrm{CaCl}_{2}$, $25 \mathrm{NaCl}$, and $50 \mathrm{NaEDTA}$, as well as the following trace minerals: $4.98 \mathrm{FeSO}_{4}, 11.42 \mathrm{H}_{3} \mathrm{BO}_{4}, 8.82 \mathrm{ZnSO}_{4}, 0.71 \mathrm{MoO}_{3}$, $0.49 \mathrm{Co}\left(\mathrm{NO}_{3}\right)_{2}, 1.44 \mathrm{MnCl}_{2}$, and $1.57 \mathrm{CuSO}_{4}$. The cultures were grown under fluorescent plant growth lights providing approximately 4000 1x of light, with light being supplied for 16 of every 24 hours. 
S. cerevisiae was used in the anodic chamber with glucose as the substrate. The medium contains the following $(\mathrm{g} / \mathrm{L})$ : $2.5 \mathrm{NH}_{4} \mathrm{Cl}, 2.91 \mathrm{Na}_{2} \mathrm{HPO}_{4}, 3.00 \mathrm{KH}_{2} \mathrm{PO}_{4}, 0.25 \mathrm{MgSO}_{4}, 0.08$ $\mathrm{CaCl}_{2}, 5.30$ citric acid, 2.50 trisodium citrate, and 3.00 yeast extract, as well as glucose at $20 \mathrm{~g} / \mathrm{L} .{ }^{13}$ These citrate concentrations give a $\mathrm{pH}$ between 4.0 and 4.1. The substrate was sterilized before use by boiling for 90 minutes. Final cultures were observed under a microscope to ensure bacterial contamination had not occurred.

\section{Electrochemical measurements}

A Gamry Reference 600 potentiostat (Gamry Instruments, Warminster, PA) was used to measure potentials and currents. For the voltage-current curves, multistep chronoamperometry software was used at several predetermined voltages between the full cell open circuit and zero voltage. Potentials were measured with respect to a saturated calomel reference electrode. Open circuit potentials were measured between the electrode in the cathodic chamber and the reference electrode in the anodic chamber.

\section{Results and discussion}

The goal of this paper was to analyze the novel composite electrode for use with the microbial cathodic half-cell described above and to find an improved microbial fuel cell configuration. As such, the first configurations examined were those of the microbial cathodic half-cell incorporating three different types of electrodes and coupled with a purely chemical anodic half-cell. Subsequently, results from a complete microbial fuel cell with both anodic and cathodic half-cells utilizing microorganisms were analyzed and compared with the results of others.

\section{Chemical anodic half-cell}

Several configurations of the fuel cell were tested. In this subsection, three different types of electrodes for the biocathodic half-cell are examined. The biocathodic half-cell was based on $C$. vulgaris and was coupled with a purely chemical anodic-half cell consisting of potassium ferrocyanide $20 \mathrm{mmol} / \mathrm{L}$.

The steady-state voltage-current behavior of the fuel cell was used to evaluate its electrical performance. The immobilized mediator electrode was compared with two other electrodes, ie, a plain graphite rod and a graphite rod coated in methylene blue. The voltage-current curves for these three cases are shown in Figure 2. The current for each datum point was taken by setting a fixed voltage until a steady-state current was reached. The bare graphite electrode with no mediator produced very little current generation, at less than $1 \mathrm{~mA} / \mathrm{m}^{2}$ short circuit current. Graphite with polymerized mediator showed much better results with a short circuit current of $8 \mathrm{~mA} / \mathrm{m}^{2}$. The composite immobilized mediator electrode

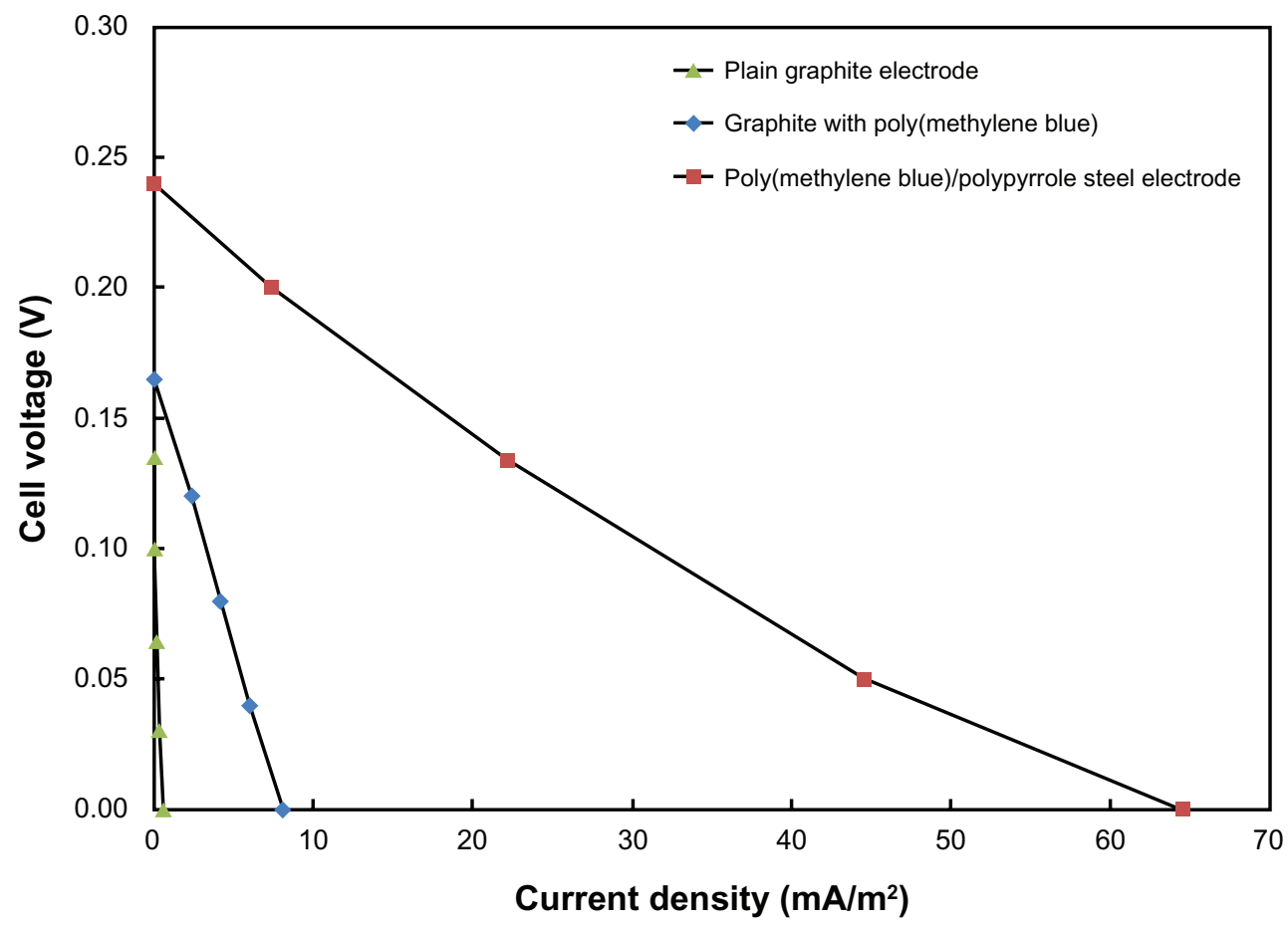

Figure 2 Voltage-current behavior in a microbial fuel cell with a biocathodic chamber and three different electrodes.

Notes: Negligible current generation is observed with plain graphite electrodes and no mediators. Current density is significantly increased with immobilized mediators. 
Table I Comparison of fuel cells incorporating a cathodic half-cell based on the microalgae Chlorella vulgaris

\begin{tabular}{|c|c|c|c|c|}
\hline \multirow[t]{2}{*}{ Parameter } & \multicolumn{2}{|l|}{ Complete MFC } & \multicolumn{2}{|c|}{ Chemical anodic half-cell } \\
\hline & Composite electrode & Powell et al ${ }^{15}$ & Composite electrode & Powell et $\mathrm{al}^{3}$ \\
\hline Open circuit voltage (V) & $0.37 \pm 0.05$ & 0.27 & $0.21 \pm 0.04$ & 0.07 \\
\hline Power density $\left(\mathrm{mW} / \mathrm{m}^{2}\right)$ & $7 \pm 2$ & I & $0.7 \pm 0.1$ & - \\
\hline Short circuit current density $\left(\mathrm{mA} / \mathrm{m}^{2}\right)$ & - & - & 65 & 24 \\
\hline
\end{tabular}

Abbreviation: MFC, microbial fuel cell.

on stainless steel showed an even higher short circuit current at $65 \mathrm{~mA} / \mathrm{m}^{2}$. Powell et al were able to obtain a short circuit current of approximately $24 \mathrm{~mA} / \mathrm{m}^{2}$ with soluble mediators in a similar setup. ${ }^{3}$ The increased current generation for immobilized mediator systems over the nonmediated systems is an indication that the mediator, methylene blue, is catalyzing charge transfer between the electrode and the microalgae. It is also apparent that methylene blue in solution causes a significant reduction of light penetration. Table 1 provides a comparison of values obtained using the composite electrode and values obtained by others using alternative electrodes. Table 1 shows the measured open circuit potential for the composite electrode incorporated into the fuel cell. The measured open circuit potential for the composite electrode was $0.21 \pm 0.4 \mathrm{~V}$, which is higher than the open circuit potential measured by Powell et al of $0.07 \mathrm{~V}$ for the case of a soluble mediator utilized in the biocathodic half-cell. ${ }^{3}$

The dynamics of the fuel cell were measured using potential steps at different cell voltages. Step times of four hours were used to determine response times to reach $95 \%$ of the final (4-hour) steady state. An example of the step change is shown in Figure 3. For this case, the step is from $370 \mathrm{mV}$ (open circuit) to $270 \mathrm{mV}$. These curves, at different voltages, were used to determine the time for steady-state polarization curves.

\section{Coupled bioanodic-biocathodic microbial fuel cell}

A complete microbial fuel cell (with both bioanodic and biocathodic half-cells) was tested for cells with both immobilized and nonimmobilized mediators. It was found that the open circuit potentials of the microbial fuel cell increased with time as the cell density increased and as the biofilm formed on the electrode. This is illustrated in Figure 4, which shows a relatively linear increase in voltage from approximately one to 3 hours. After approximately 4 hours, the open circuit voltage reached a relatively stable steady-state value, likely due to an optimum cell density and an end to net cell growth.

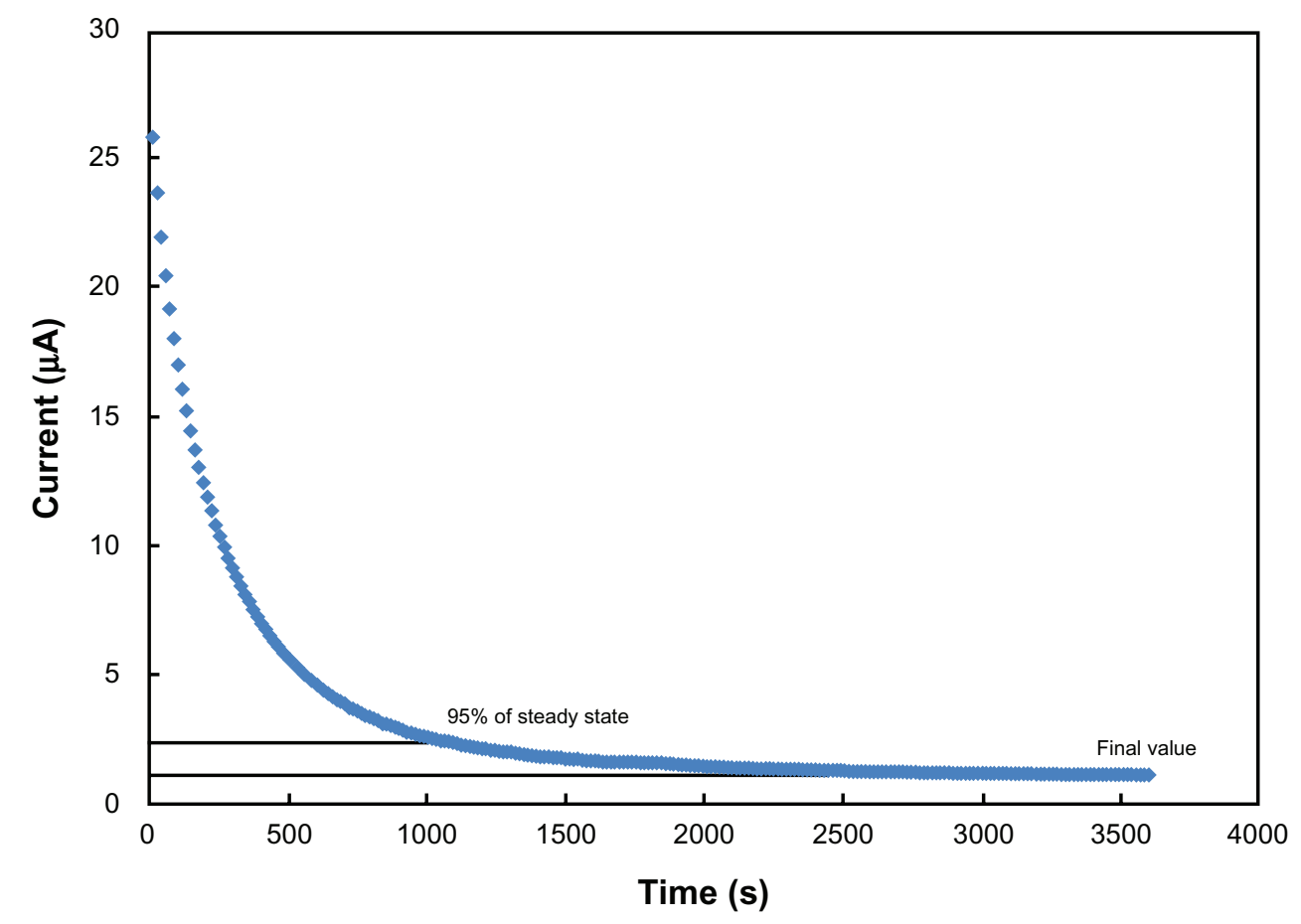

Figure 3 Response to step change in voltage of the immobilized mediator microbial fuel cell. 


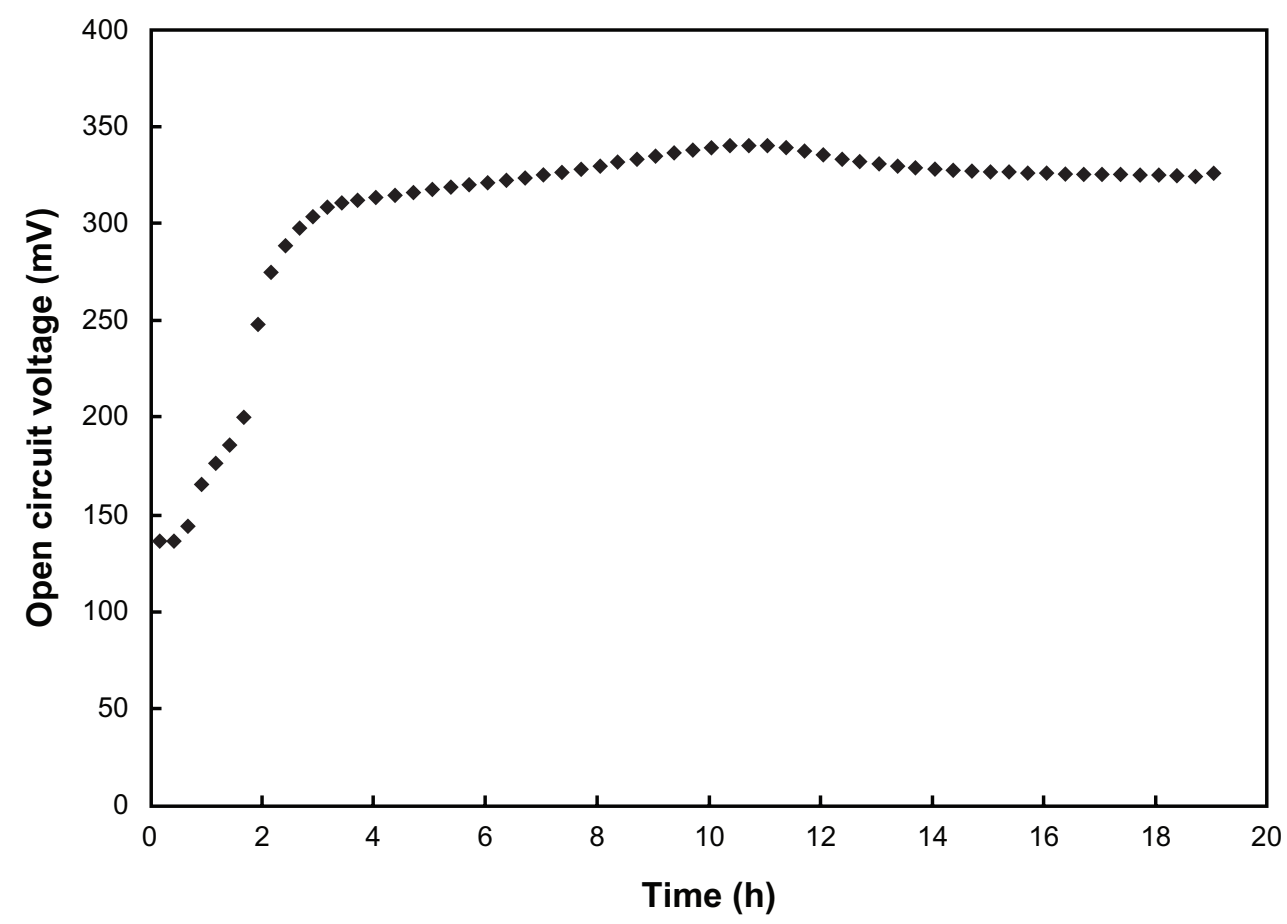

Figure 4 Coupled microbial fuel cell open circuit voltage over time after inoculation.

Figure 5 shows the voltage, current, and power characteristics of the microbial fuel cell with $S$. cerevisiae in the anodic chamber and C. vulgaris in the cathodic chamber. A composite immobilized mediator steel electrode [polypyrrole and poly(methylene blue) on $304 \mathrm{~L}$ stainless steel] was used as the cathode and a graphite electrode with soluble methylene blue was used in the anodic chamber. This shows a larger maximum current and power density than that achieved with any other electrode configuration and similar volumes, including a soluble mediator in both chambers as reported by Powell et a ${ }^{15}$ and

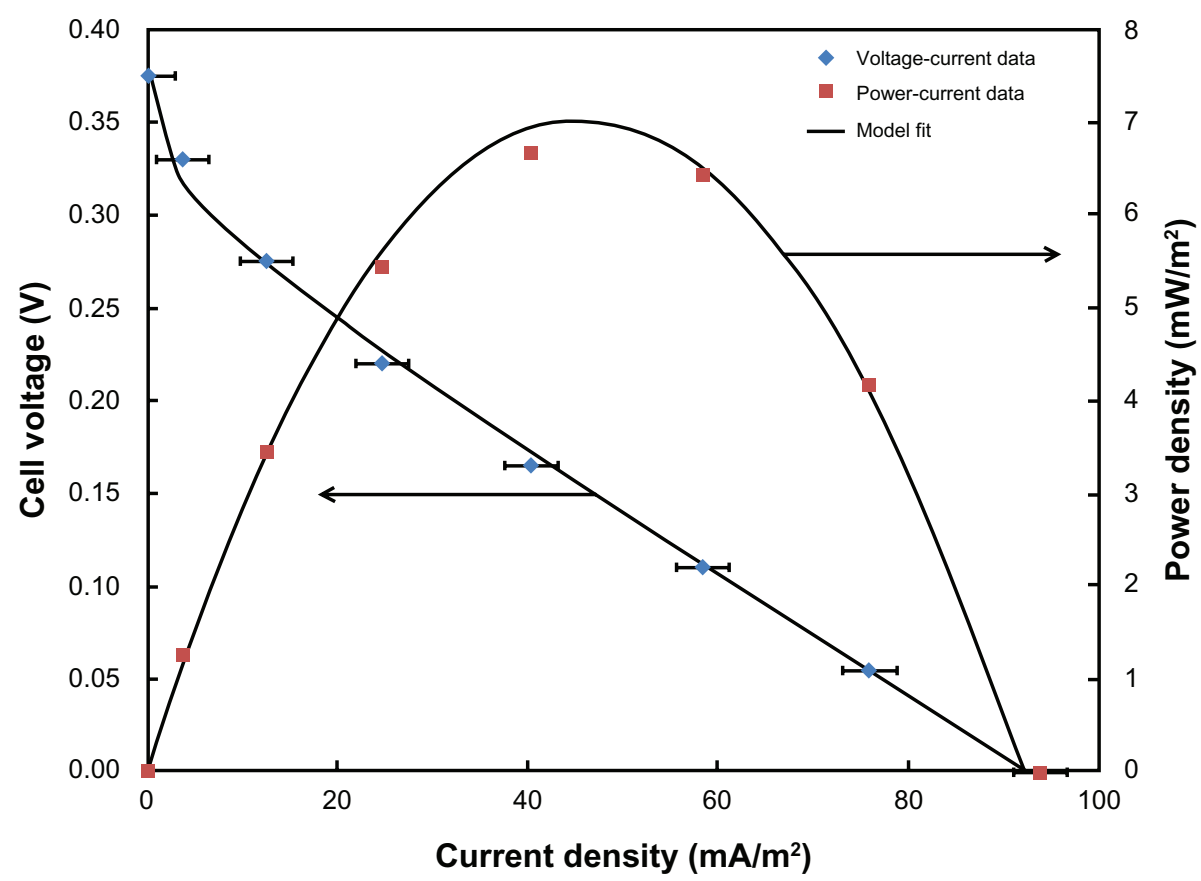

Figure 5 Polarization and power curves for a microbial fuel cell with bioanodic and biocathodic chambers with soluble mediator and graphite anode and immobilized mediator steel cathode along with fit to basic model.

Note: Error bars show the relative standard deviation of current measurements. 


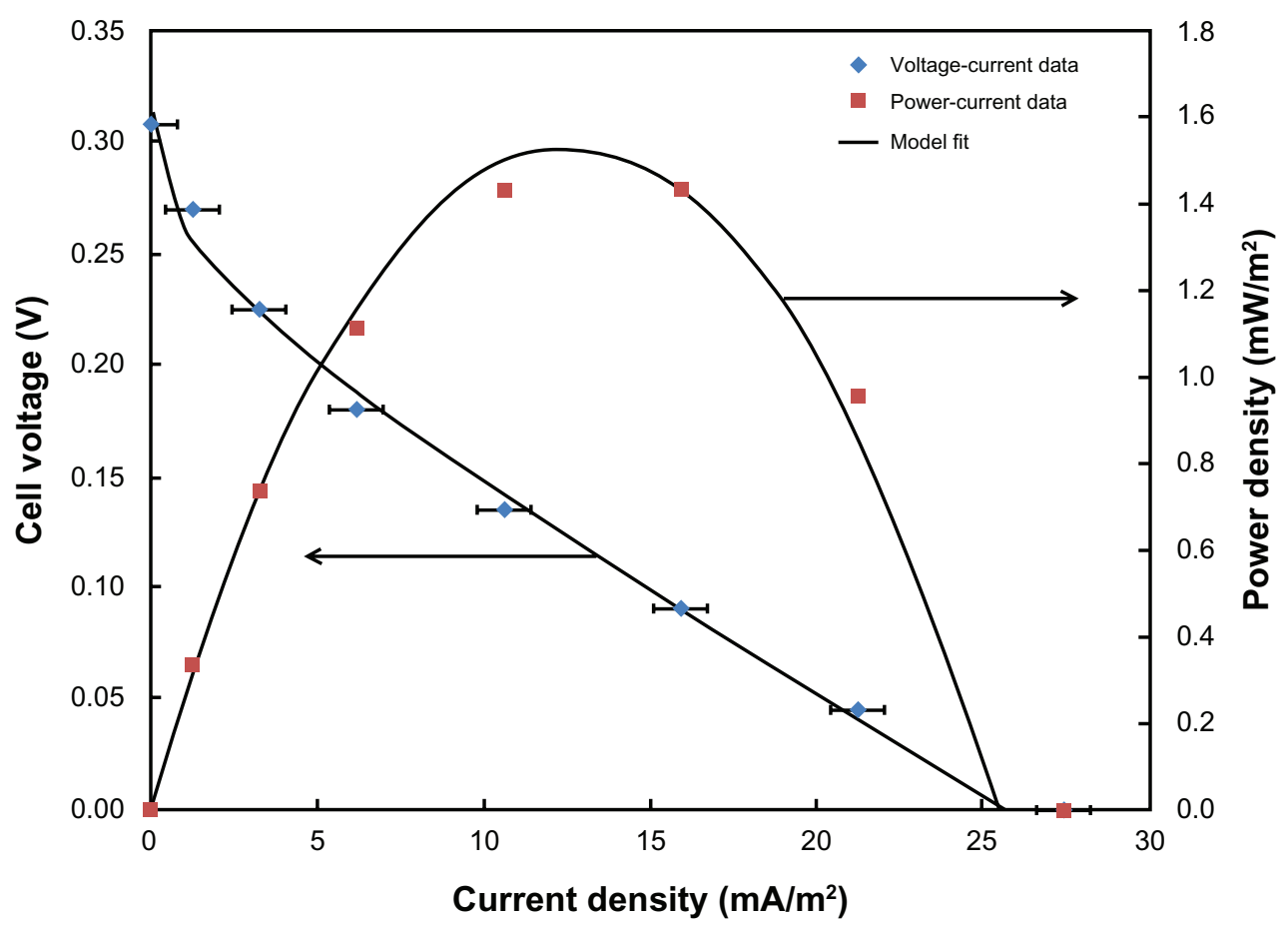

Figure 6 Polarization and power curves for microbial fuel cell with bioanodic and biocathodic chambers, each with an immobilized mediator steel electrode. Notes: Electrochemical resistance model fit lines shown. Error bars show the relative standard deviation of current measurements.

compared in Table 1. Power density, also shown to be normalized to the electrode surface area, was calculated from the voltage and current data and plotted. The error bars show the relative standard deviation of current measurements between three duplicate runs on the same experimental setup.
The microbial fuel cell was also operated with the novel composite electrodes in the anodic and cathodic chambers. Immobilized mediators have not been shown to be effective with yeast anodic half-cells, although there is some disagreement between researchers regarding the role of

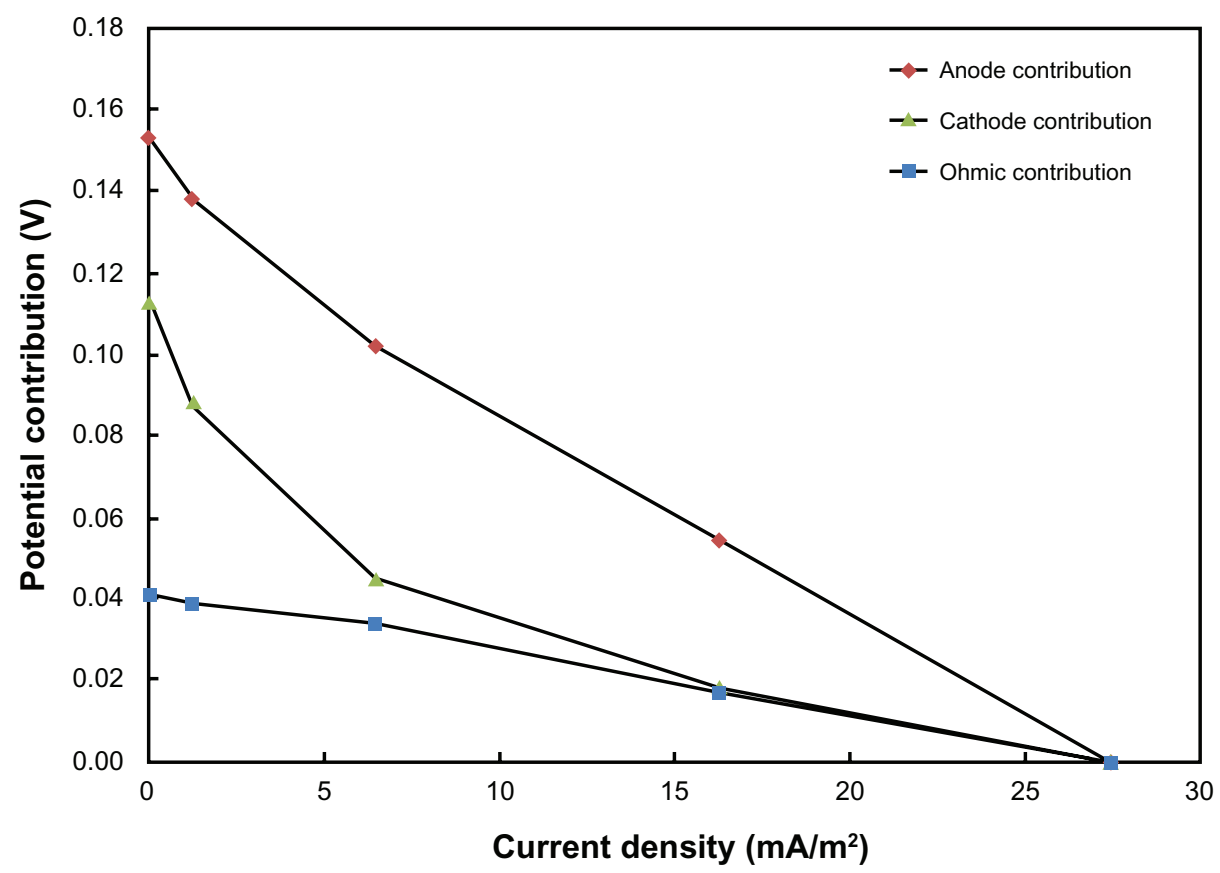

Figure 7 Resistance of anode, cathode, and electrolyte with bioanodic and biocathodic chambers with immobilized mediator electrodes used for each. Note: The negative slope of each line corresponds to the internal resistance of the given component at that current. 
mediators in such systems. ${ }^{16}$ The resulting voltage, current, and power relationships from this microbial fuel cell are shown in Figure 6. By comparing Figures 5 and 6, it can be seen that the immobilized mediator has a detrimental effect on the performance of the bioanodic half-cell with $S$. cerevisiae. The maximum power density decreased by a factor of 4.5 from $7 \mathrm{~mW} / \mathrm{m}^{2}$ to $1.5 \mathrm{~mW} / \mathrm{m}^{2}$.

A typical fuel cell electrochemical resistance model was used to model the microbial fuel cell, without considering mass transfer limitations, as shown in Equation (3): ${ }^{17}$

$$
E=E^{o}-(a+b \ln i)-R_{\Omega} i
$$

where $E$ is the cell potential, $E^{o}$ is the equilibrium potential, $a$ and $b$ are terms for the activation resistance, and $i$ is the current density. Results from this model are shown in Figures 5 and 6 as solid lines. The mass transfer term has been eliminated because there is no indication of mass transfer limitation in this or other similar microbial fuel cells.

In order to separate the effects of the electrolyte and membrane from those of the microbial metabolism and electrode interaction, voltage differences were measured between the working electrodes and two reference electrodes. For this, the voltage current curve was measured as previously, but with the voltage across the membrane and between the reference electrodes and their associated working electrode. The voltages are plotted in Figure 7 with respect to their values at short circuit. From this diagram, it can be seen that most of the internal resistance comes from the anode, with the membrane and electrolyte contributing only $13 \%$ of the overall internal resistance.

\section{Conclusion}

A microbial fuel cell with a photosynthetic biocathodic halfcell and $\mathrm{CO}_{2}$ as the electron acceptor was operated successfully with several combinations of electrodes and anodic half-cell configurations. The cathodic half-cell relied on $C$. vulgaris microalgae for photosynthesis. Composite polypyrrole/ poly(methylene blue) mediators were found to offer higher electrical performance in these half-cells than soluble mediators, immobilized mediators on graphite, or mediatorless systems.

A completely biological fuel cell was operated with a bioanodic half-cell based on $S$. cerevisiae metabolizing glucose along with the biocathodic half-cell. The electrochemical experiments with the bioanodic half-cell showed that this half-cell performs better with soluble mediators than the immobilized mediator electrodes in contrast with the biocathodic half-cell. This indicates that interaction between the yeast cells and the electrode is limited when the mediator is unable to diffuse fully into the cells. The complete microbial fuel cell comprised of bioanodic and biocathodic half-cells had better performance than previous systems when a soluble mediator-based anodic half-cell was combined with an immobilized mediator-based cathodic half-cell. It was also determined that most of the internal cell resistance is associated with the anode in an optimum system.

\section{Disclosure}

The authors report no conflicts of interest in this work.

\section{References}

1. Gregory KB, Bond DR, Lovley DR. Graphite electrodes as electron donors for anaerobic respiration. Environ Microbiol. 2004;6: 596-604.

2. Rabaey K, Read ST, Clauwaert P, et al. Cathodic oxygen reduction catalyzed by bacterial in microbial fuel cells. ISME J. 2008;2:519-527.

3. Powell EE, Mapiour ML, Evitts RW, Hill GA. Growth kinetics of Chlorella vulgaris and its use as a cathodic half cell. Bioresour Technol. 2009;100:269-274.

4. Erable B, Vandecandelaere I, Faimali M, et al. Marine aerobic biofilm as biocathode catalyst. Bioelectrochem. 2010;78:51-56.

5. Cournet A, Délia ML, Bergel A, Roques C, Bergé M. Electrochemical reduction of oxygen catalyzed by a wide range of bacteria including Gram-positive. Electrochem Commun. 2010;12:505-508.

6. Cao X, Huang X, Liang P, et al. A completely anoxic microbial fuel cell using a photo-biocathode for cathodic carbon dioxide reduction. Energy Environ Sci. 2009;2:498-501.

7. Park DH, Zeikus JG. Improved fuel cell and electrode designs for producing electricity from microbial degradation. Biotechnol Bioeng. 2003;81:348-355.

8. Feng C, Ma L, Li F, Mai H, Liang X, Fan S. A polypyrrole/anthraquinone2,6-disulphonic disodium salt (PPy/AQDS)-modified anode to improve performance of microbial fuel cells. Biosens Bioelectron. 2010;25:1516-1520.

9. Qiao Y, Li CM, Bao SJ, Bao QL. Carbon nanotube/polyaniline composite as anode material for microbial fuel cells. J Power Sources. 2007;170:79-84.

10. Morozan A, Stamatin I, Stamatin L, Dumitru A, Scott K. Carbon electrodes for microbial fuel cells. J Optoelectron Adv Mater. 2007;9: 221-224.

11. Dumas C, Mollica A, Féron D, Basséguy R, Etcheverry L, Bergel A. Marine microbial fuel cell: use of stainless steel electrodes as anode and cathode materials. Electrochim Acta. 2007;53:468-473.

12. Manohar AK, Mansfeld F. The internal resistance of a microbial fuel cell and its dependence on cell design and operating conditions. Electrochim Acta. 2009;54:1664-1670.

13. Wall JB, Hill GA. Optimum CFST bioreactor design: experimental study using batch growth parameters for Saccharomyces cerevisiae producing ethanol. Can J Chem Eng. 1992;70:148-152.

14. Godwin JM, Evitts RW. Polypyrrole/poly(methylene blue) composite electrode films on stainless steel. Electrochem Soc Trans. 2011;33: 181-188.

15. Powell EE, Bolster JC, Hill GA, Evitts RW. Microbial fuel cell with a photosynthetic microalgae cathodic half cell coupled to a yeast anodic half cell. Energy Sources Part. 2011;33:440-448.

16. Liu Y, Li W, Hu X, Yin Y. The study of mediator-less microbial fuel cell based on saccharomyces cerevisiae. Mechatron Embedded Syst Appl. 2010:361-363.

17. O'Hayre R, Cha SW, Colella W, Prinz FB. Fuel Cell Fundamentals. New York, NY: Wiley \& Sons; 2006. 
Reports in Electrochemistry

\section{Publish your work in this journal}

Reports in Electrochemistry is an international, peer-reviewed, open access journal publishing original research, reports, reviews and commentaries on all areas of electrochemistry. The manuscript management system is completely online and includes a very quick and fair

to read real qustem. Visit http://www.dovep

Dovepress

Submit your manuscript here: http://www.dovepress.com/reports-in-electrochemistry-journal 